\title{
A REVISED DATE FOR PENTATEUCHAL TEXTS? EVIDENCE FROM KETEF HINNOM
}

\author{
Erik Waaler
}

\section{Summary}

The trend of OT scholarship is to date Pentateuchal texts to exilic or postexilic times. The silver amulets from Ketef Hinnom may challenge this conclusion. Based on archaeological and palaeographic studies, the amulets are dated between 725 and 650 BC. The amulets contain material from the Priestly source (Nu. 6:24-26) as well as from the frame of Deuteronomy (Dt. 7:9). It is argued that the person who inscribed the silver plates is likely to have used a single source for these two quotations, a source that probably included more Pentateuchal material. Thus disparate Pentateuchal texts existed and were conjoined prior to the reform of Josiah. If it is reasonable to posit a lapse of time for this early version to become influential and the accidental inscription of the amulets to occur, the extended source text must be yet earlier.

Some decades ago the Ryland Papyrus sent an earthquake into New Testament research. Before this papyrus was published, several NT scholars dated the Gospel of John to the middle or late second century AD. The appearance of the Ryland Papyrus, dated to about AD 130, posed a serious obstacle to such a late dating of the Gospel of John. ${ }^{1}$ Most scholars today are of the opinion that the Gospel of John must

1 The date of the papyrus cannot be fixed beyond any doubt. However, a consensus concerning the date in the first half of the second century seems to have emerged (see B.M. Metzger, The Text of the New Testament: Its Transmission, Corruption, and Restoration (3rd edn; New York / Oxford: OUP, 1992), 38-39; K. Aland \& B. Aland, Der Text des Neuen Testaments (Germany: Deutsche Bibelgesellschaft, 1982), 94; S. Giversen, Det Nye Testamentets Teksthistorie (København: G.E.C. Gad, 1978), 37-38. 
have been written before $A D 100$ and not a few would date it somewhat earlier. ${ }^{2}$

The silver amulets from Ketef Hinnom may pose a similar challenge to some theories concerning the Pentateuch. ${ }^{3}$ According to Wellhausen, the Pentateuch was written in the period from the 10th to the 5th centuries BC, with the Priestly source as the latest one added in the fifth century, and the main part of Deuteronomy dated to the time of Josiah (640-609 BC). ${ }^{4}$ Generally the Jahwist (J) has been dated to the 10th or 9th century, ${ }^{5}$ the Elohist (E) to the 9 th or 8 th, ${ }^{6}$ and the Priestly source (P) after the exile. ${ }^{7}$ Some dated Deuteronomy after the Priestly source. ${ }^{8}$ 'The chronological sequence of J-E-D-P adopted by Wellhausen and others in the late nineteenth century has come to be called the classical form of the source hypothesis. ' 9 Today there seems to be no consensus about this hypothesis. ${ }^{10}$ At the same time the 'early' dates of the material in the J, E and D sources are being abandoned, the collecting and editing of the material being dated to the exile or post-exilic period. ${ }^{11}$

2 Cf. K. Berger, Im Anfang war Johannes: Datierung und Theologie des vierten Evangeliums (Stuttgart: Quell, 1997), 11-13; L.L. Morris, The Gospel According to John: The English Text with Introduction, Exposition and Notes (Grand Rapids, Michigan: Eerdmans, 1987[1971]), 30; R. Schnackenburg, Das Johannesevangelium (vol. 1; Freiburg / Basel / Wien: Herder, 1972), 62.

3 Cf. E. Waaler, 'Sølvamulettene fra Ketef Hinnom', Tidsskrift for Teologi og Kirke [henceforth: TTK] 4 (1999) 267-74.

4 Ca. 621; so A.F. Campbell \& M.A. O'Brien, Sources of the Pentateuch: Text, Introductions, Annotations (Minneapolis: Fortress, 1993), 5; Cf. G. von Rad, Deuteronomy: A Commentary (OTL; London: SCM, 1974[1966]), 27-28; M. Weinfeld, Deuteronomy and the Deuteronomic School (2nd edn; Oxford: Clarendon, 1983[1972]), 179-80; R.K. Harrison, Introduction to the Old Testament (Grand Rapids, MI: Eerdmans, 1983), 21. O. Kaiser seems to conclude with a post exilic date for Deuteronomy (Einleitung in das Alte Testament: Eine Einführung in ihre Ergebnisse und Probleme [Gütersloh: Gütersloher Verlagshaus, 1975], 123).

5 Ca. 950, G. von Rad, Das Erste Buch Mose: Genesis (ATD vol. 2/4, 8th edn, Göttingen: Vandenhoeck \& Ruprecht, 1967), 16; ninth century, but including older material, H. Gunkel, Genesis (9th edn; Göttingen: Vandenhoeck \& Ruprecht 1977[1901]), XIX-XX.

6 Ca. 850-750 (von Rad, Erste Buch Mose, 16); 8th century, but including older material (Gunkel, Genesis, XIX).

7 538-450 (von Rad, Erste Buch Mose, 16; cf. Weinfeld, Deuteronomy, 179).

8 Weinfeld, Deuteronomy, 180.

9 Campbell \& O'Brien, Sources, 5.

10 Cf. J. Blenkinsopp, The Pentateuch: An Introduction to the First Five Books of the Bible (Anchor Bible Reference Library; New York: Doubleday), 25.

11 Cf. Campbell \& O'Brien, Sources, 10-11, and Blenkinsopp, Pentateuch, 25-26. T. Stordalen argues that the author of Gn. 1-11 wrote between 537 and 450 BC ('Urhistorien: med skapelsesberetningen og edenfortellingen', Det gamle 


\section{The Silver Amulets and Their Archaeological Dating}

Two silver amulets were found in the excavations at Ketef Hinnom carried out by Barkay and his team in the period from 1975 to 1989.12 Ketef Hinnom is situated beside St. Andrew's church at the edge of the Hinnom valley. ${ }^{13}$ The amulets were found in cave 24 , chamber 25 , in a repository under the tomb, where the remains of the bodies were moved when new bodies needed the space in the tomb. The cave was probably hewn before the Babylonian conquest of Jerusalem. ${ }^{14}$ The pottery in the repository can be dated to two main periods: 'the early stage - 7th and early 6th centuries B.C.E.; and the later stage-from the mid-6th to the early 5th century B.C.E.' ${ }^{15}$ The first amulet was found about $7 \mathrm{~cm}$ above the floor, whereas the average depth of remains in the repository was about $65 \mathrm{~cm} .{ }^{16}$ Based on the place of finding, the first silver amulet seems to belong to the early stage of the first period. ${ }^{17}$ The second amulet was found at the inner section of the

testamentet: analyse av tekster $i$ utvalg [ed. M. Kartveit, Oslo: Samlaget, 2000], 26). However, if Ne. 8:8 speaks of translation of the text (i.e. from Hebrew to Aramaic), this would indicate an earlier date for Deuteronomy, as it is unlikely that Deuteronomy was written in a language that was not in common use at the time of writing. The absence of any focus on the king is difficult to understand if Deuteronomy was written during the exile or in the period of the monarchy (but see Dt. 17). A full discussion of these matters is beyond the scope of this article.

12 G. Barkay, Ketef Hinnom: A Treasure facing Jerusalem's Walls (Jerusalem: Israel Museum, 1986), 9.

13 Barkay, Ketef Hinnom, 10.

14 'The hewing of rock-cut burial caves in Ketef Hinnom was a result of the expansion of the city to the far end of the Western Hill- today the Jewish and Armenian quarters of the Old City and mount Zion-from the 8th century B.C.E. on' (G. Barkay, 'Excavations at Ketef Hinnom in Jerusalem', Ancient Jerusalem Revealed [ET H. Geva; Jerusalem: Israel Exploration Society, 1994], 105). 'It is unlikely that burial caves continued to be cut into the rock by wealthy families after the Babylonian conquest, therefore our caves must have been hewn and used before that date, a conclusion supported by the analysis of the pottery and other finds from the repository' (G. Barkay, 'The Priestly Benediction on Silver Plaques from Ketef Hinnom in Jerusalem', Journal of the Institute of Archaeology of Tel Aviv University 19,2 [1992] 147).

15 Barkay, 'Priestly Benediction', 147.

16 Barkay, 'Priestly Benediction', 145, 148. Barkay actually describes the average depth as ' $0.65 \mathrm{~cm}$ ' (p. 145). The context seems to indicate that the average depth must have been $0.65 \mathrm{~m}$. This is evident from the pictures (p. 146, fig. 8) and the comment about the first amulet being buried 'close to the floor', i.e. $7 \mathrm{~cm}$ above the floor (p. 148). Granted the great number of items found, it is unlikely that the average depth was $6.5 \mathrm{~mm}$.

17 'Its location close to the floor indicates its relative antiquity compared with the other finds recovered here' (Barkay, 'Priestly Benediction', 148). 
grave indicating that it belongs to the early stage. ${ }^{18}$ The cave seems to have been in use from about the middle of the seventh century BC. ${ }^{19}$ Thus a date as early as $650-600$ BC seems reasonable. ${ }^{20}$ The archaeological evidence makes it improbable that the amulets are any later than the sixth century BC. Thus our palaeographic investigation is limited to the sixth century and earlier.

As the amulets could have been in use for some time before they followed their owners into the grave, it is possible that the amulets might be older than the other items found in the repository. This is supported by Barkay's description of the first amulet: 'The outer edges of the roll were worn and split, indicating that it had been worn on the body in antiquity.' 21 Secondly, a part of the amulet has been changed: in line six some letters have been smoothed out and new letters inscribed in the same place. In line seven there is a new layer of silver with an inscription. ${ }^{22} \mathrm{~A}$ reasonable guess would be that, when the amulets were put into the grave, they had been in use for a generation. If this was the case, the amulets could have been made in the first half of the seventh century $(700-650 \mathrm{BC})$.

Although we cannot assume that the persons who used the amulets were literate, it is reasonable to assume that the literacy involved in inscribing the amulets was an upper class phenomenon. Granted the presence of the priestly blessing on the amulets, the writing material, and the finding place in Jerusalem, it is likely that somebody associated with the priests in the temple made the amulets. ${ }^{23}$

18 'Although no stratification could be discerned, it may be assumed that the earliest finds lay upon the rock floor. Furthermore, the finds deriving from the innermost portions of the repository farthest from the aperture and close to the western wall (Squares A, B) must also be the oldest, due to the fact that when human remains and burial gifts were introduced into the repository, the older deposits were pushed further inside. Remains of at least 95 individuals were uncovered here, indicating that the cave was used for an extended period of time. Over 1000 items were uncovered in the repository' (Barkay, 'Priestly Benediction', 145). Barkay further indicates that the pottery found belongs to 'two equal parts' (Barkay, 'Priestly Benediction', 147), indicating that half of the findings belongs to the early period.

19 Barkay, 'Priestly Benediction', 29.

20 Cf. Waaler, 'Sølvamulettene'.

21 Barkay, 'Priestly Benediction', 148; 'The scrolls seem to have been worn for a long time and as a result were in poor condition, especially at the two ends' (Barkay, 'Excavations', 102).

22 Barkay, 'Priestly Benediction', 155.

23 There seems to be general agreement that the text was produced by priests: 'The appearance of silver plaques of inscriptions resembling the priestly benediction recalls the priestly connection to writing-particularly on precious materials (see Exodus 39:30 and 28:36)' (Barkay, 'Priestly Benediction', 175). See 


\section{Dating Based on Palaeographic Evidence}

Based on palaeographic evidence the dating has been variously assessed. ${ }^{24}$ Most scholars have dated the two amulets to the late seventh or early sixth century $\mathrm{BC}$, but Renz dates them to the early post-exilic period or to one of the two centuries leading up to the Christian era. ${ }^{25}$ Based on archaeological evidence it seems justifiable to search for parallels in the sixth century or earlier. Barkay has made the following observation:

The letters on the plaques have long, slanting legs-an indication of their relative antiquity, as Cross emphasized in his discussion of the 'barley ostracon' from Samaria (Cross 1962a:36). The cursive script on ostraca from the late Monarchy reflects a general tendency to contract letters and shorten the vertical legs. ${ }^{26}$

The ostracon from Samaria has been dated to the second half of the eighth century. 27

The aleph has two parallel strokes, a form which started to appear at the end of the eighth century [†]. This practice is different from

also Ps. 12:7, Pr. 10:20, 1 Ch. 29:4, Je. 10:9, Ex. 39:3, Nu. 17:3; Je. 17:1, Is. 8:1 (cf. Barkay, 'Priestly Benediction', 174-75). 'It is quite likely that the written blessing was provided by the priests upon request, as was the spoken blessing' (Barkay, 'Priestly Benediction', 180). 'Because of the priestly context in which the blessing appears in the Bible and also in the Rule of the Community from Qumran, there still remains the question whether in early times such amulets were commonly used or only by priests' (A. Yardeni, 'Remarks on the Priestly Blessing on Two Ancient Amulets from Jerusalem', VT 41 [1991] 185). A similar but more general conclusion is drawn by Naveh about the script in a burial chamber at Bet Layy dated by him to the time of Hezekiah: 'Since it is unlikely that many ordinary folk were acquainted with the art of writing, the explanation that a number of Levites visited this cave is relatively plausible' (J. Naveh, 'Old Hebrew Inscriptions in a Burial Cave', Israel Exploration Journal Reader, [vol. 2, ed.. H.M. Orlinsky, New York: Ktav, 1981], 776). We will argue that the silver plaques are part of a written tradition that the plaques have in common with Pentateuchal material. Such documents as Pentateuchal texts are likely to have been present in the temple and probably in the royal court. It is of course possible that such a source document was available in other places as well. Multiple copies might imply a more advanced stage in the textual transmission process.

24 Palaeography is not an exact science as the form of the letters varies from one location to another (A. Aschim, 'Typologisk metode og Bibelforskning', TTK 70 [1999] 275-93). Thus the dates given below are approximations. When other sources are not mentioned, the descriptions are based on the material in Johannes Renz, Handbuch der Althebräischen Epigraphik (3 vols., Darmstadt: Wissenschaftliche Buchgesellschaft, 1995).

25 Cf. Renz, Handbuch 1, 447-8. Barkay dates the amulets in the second half or last quarter of the seventh century ('Priestly Benediction', 174). Yardeni dates it in the early sixth century ('Remarks', 180).

26 Barkay, 'Priestly Benediction', 170.

27 Renz, Handbuch 1, 140, cf. pp. 135-44. 
the earlier form of the aleph which consists of a $v$-formed pair of strokes crossing the vertical bar open to the right. This form dominates up to the middle of the eighth century, coexists with the two parallel strokes in the eighth and seventh century, and then regains dominance in the sixth century [ $\$$ ]. On plaque one the two parallel strokes in the aleph cross over the vertical bar [ $\neq$ ]. Evidence for this is found in the last quarter of the eighth century and the first half of the seventh century. ${ }^{28}$

The beth on the first plaque has a long leg which is slightly slanted downwards to the left, and a base that is only slightly slanted (see 1.4) [4]. The combined leg and base seems to be long (11. 4, 9 and 11). This is an ancient form, found predominantly before the middle of the seventh century. ${ }^{29}$ However, later examples are also extant (cf. Arad (6):10), and thus no firm conclusion can be made on this basis. ${ }^{30}$ The beth on plaque two is more slanted, with a curved but long leg, making it more cursive [4]. On both amulets the head is formed as a triangle. Thus the head is not rounded. The strongest argument for an earlier date for the letter beth is its long leg.

The only gimel is found on plaque one, line 11 . The top of the letter makes the identification somewhat uncertain. The slanted letter, with a 90 degree angle between the horizontal stroke and the long leg, is typical of the period between $750-675 \mathrm{BC} Y \mathrm{~J} \cdot{ }^{31}$

There is one clear daleth on the first amulet (1.5) [ ]. This letter has a relatively long leg that is typical for the period $725-600$, and

28 Renz, Handbuch 2/1, 103, 105; Seb (8):5, Gib (7):1, Jer (7):15; see however Arad (7):97 and Lak (7/6):27 (Renz, Handbuch 3, Tf. 26 and 27), both of which have such bars crossing over, but not with an equal half on each side such as in the earlier forms. Renz gives a similar date to the letter, arguing that the form of the letter reappears in the first century BC (Handbuch 1, 450). Avigad says about a Hebrew seal with a running ibex: "The lower horizontal of the alef crosses the vertical shaft, an unusual feature in the seventh century' [N. Avigad \& B. Sass, Corpus of West Semitic Stamp Seals (Jerusalem: Institute of Archaeology, Hebrew University, 1997), 75]. Due to the picture this seal might well be prior to the reform of Josiah (Avigad \& Sass, Corpus, 45-46, cf. p. 95, no 147, p. 128, no. 267).

29 Cf. Renz, Handbuch 2/1, 113.

30 Renz, Handbuch 3, Tf. 29.

31 Renz, Handbuch 2/1, 114, type c and d. The example Renz states from the 6th century BC has a different angle and a shorter and more horizontal stroke at the top (Arad (6)110, Renz, Handbuch 3, Tf. 31). 
then vanishes again. ${ }^{32}$ The rounded head is present from the end of the eighth century onwards. .33

With regard to the he, there is considerable variation on the two silver amulets. One he with two horizontal strokes is found on plaque one, but this letter is fairly uncertain [기]. The typical he has different lengths for the three horizontal strokes. However, there is no norm as to which stroke is the longest [ $\Rightarrow$ f $=$. $]$. On plaque one there are some examples in which the upper horizontal stroke does not touch the vertical bar, but is found a little above it. This feature is found from the end of the eighth century through the seventh century [ E]. ${ }^{34}$

Apart from the standard $h e$, there are several variations that are found predominantly in the name of Yahweh. A he with all three lines crossing the vertical bar is found on the first amulet line 15 and the second amulet lines 6 and 8-9, all of them in the name of Yahweh [乎]. A parallel to this is found on Arad ostracon 31 (seventh century BC) in a name that is a combination with the name of God (i.e. Yahweh). ${ }^{35}$ A similar combination of different shapes of the letter he is found in Bet Layy (7):2, a text from the end of the eighth or the beginning the seventh century. ${ }^{36}$ In this grave inscription the first he in the name of God, Yahweh, has three parallel strokes, two of which go through the vertical bar. The second he has only two horizontal strokes, both of which go through the vertical bar. ${ }^{37}$ On both the silver plaques from Ketef Hinnom we find a he with yet another shape. According to Renz '.. eine Form, bei der sich die mittlere und untere Horizontale links treffen und ein Dreieck bilden, während die obere

32 Renz type m, n and o (Renz, Handbuch 2/1, 117).

33 Cf. Renz, Handbuch 2/1, 119. Renz describes it as type 'l', a form that is present at the beginning of the 7th century (Renz, Handbuch 1, 450), but it is more like his letter ' $i$ ' a form from the end of the 8th and beginning of the 7th century (Renz, Handbuch 2/1, 117). However, the letter on the silver plaque has a longer leg.

34 Renz, Handbuch 3, Tf. 11-12 Arad (8):51,59, Tf. 15 Kom (8):1, Tf. 25 Arad (7):31.

35 Cf. Renz, Handbuch 3, Tf. 35 Arad (7):31 (cf. Blay (7):2). Ostracon 31 has been variously dated to the end of the eighth century, beginning of the seventh century, and the end of seventh century. A similar shape of the he is found in texts from the second part of the seventh century onwards in Jer (7):5, Arad (6):5 and Arad (6): 111 (Renz, Handbuch 3, Tf. 26, Tf. 29 \& Tf. 32). In these texts the he generally has much shorter legs than the silverplates. The longest leg from this period is found in Arad (7):31 (Renz, Handbuch 3, Tf. XXXV, 1), however, even this letter has a shorter leg than those in plate one lines 8 and 10 (cf. line 9, 12 and 15).

36 Renz, Handbuch 1, 244.

37 Cf. Renz, Handbuch 3, Tf. 25, BLay (7):1. 
Horizontale rechts oben überstehst (Jer(x):34 Z.9) ist nur in den ersten beiden Jhdten. v. Chr. belegt ...'38 [ ]. However, a similar shape is found at the very beginning of the seventh century, in Bet Layy ${ }^{39}$ and on some ancient seals. ${ }^{40}$ Another he with two strokes forming a triangular head is found on the second plaque [4]. Such a form is also found in Bet Layy $\$ .41$ The combined evidence speaks for a date around the end of the eighth or the beginning of the seventh century.

The shape of the waw on the two silver plaques makes it probable that the date is later than the middle of the eighth century. At this particular point in time we see a transformation of this letter from a $Y$ form with two strokes [ $Y$ ], to a three stroke letter [ $\mathcal{Y}$. The head of the letter is curved to the left, and the second stroke is almost horizontal, but slanted from the right end down to the left end. The third stroke is a vertical bar, slanted from the left down to the right end $[\hat{~}]$. This kind of letter is found from the middle of the eighth century. ${ }^{42}$ It is important to note that the letter seems to be written with three separate strokes on plaque one. This might be a sign of early origin: 'Im ausgehend 8. Jhdt. begegnen daneben mehrere Varianten dieser Form ... zudem ist in der Kursive die Tendenz festzustellen, diese Dreistrichform nun in einem Zug zu schreiben, so daß letztlich eine Einstrichform entsteht.' 43 One waw on plaque one (1. 12) lets the lower part of the half circular head continue beyond the vertical bar. Thus the horizontal stroke points downwards to the left, starting from the vertical bar [ 7 ]. The only parallcl that I have been able to find is from Bet Layy (7):2,44 dated to the turn of the century

\footnotetext{
38 Renz, Handbuch 1, 450.

39 Renz, Handbuch 3, Tf. 19 / Tf. XXV, no. 3, 1. 1 BLay (7):1.

40 Avigad \& Sass, Corpus, 232-33, seal 629, 1. 2; cf. p. 210, seal 542; p. 200, seal 501.

41 Renz, Handbuch 3, Tf. 20 BLay (7):4.

42 Renz, Handbuch 3, Tf. 1-6, 7-34. There is a possible exception, or transitional form, in the Samaria ostraca (Sam (8):1), which are dated to different parts of the eighth century. Based on palaeographic evidence these ostraca have been dated to the second half of the eighth century (Renz, Handbuch 1, 86). Renz argues that this form is not found prior to the exile, but he admits that the form at Bet Layy is similar to it (Renz, Handbuch 1, 451). The clear distinction between the three strokes found in the amulets is rare, but some examples can be found (e.g. Sam (8):4; BLay (7):2; Kom (8):1).

43 Renz, Handbuch 2/1, 135.

44 Renz, Handbuch 3, Tf. XXV:2, i.e. the left drawing made by Naveh, the last line and the second last character.
} 
(701 $\mathrm{BC}$ ?) [f] $] .45$ The second plaque has a letterhead that is formed as an inverted $z$, a letter form occurring for the first time at the end of the eighth century [千].

There is one heth on plaque one, but it is so damaged that it is difficult to assign a particular age to it [ The width of the letter could support a later date, but similar wide letters are also found earlier (Arad (8):100, Sam (8):11, Rrah (7):1; cf. Jer (7):16, Kom (8): 1$) .46$

The tail of the yodh, the lowest horizontal stroke to the right [Z], starts to vanish in the seventh century and with a few exceptions it is absent in the sixth century [7].47 On plaque one, the yodh has a regular and long tail [Z], whereas some of the yodhs on plaque two have shorter tails [Z]. This might indicate a slightly younger age. In the last quarter of the eight century and in the first half of the seventh, there was a tendency to drop the middle stroke. This tendency is present on plaque two [2]..$^{48}$ Later, when the tail was dropped, the middle stroke is consistently present. Plaque two has a yodh with a triangular head [ $Z$ ]. Yardeni describes the triangular head of the yodh as a late seventh century phenomenon. ${ }^{49}$ This conclusion is based on the form of the yodh in the Mesad Hashaviyahu letters (ca. $625 \mathrm{BC}$ ). However, there are several examples in these letters where the tail of the yodh is shortened or void [7]. The yodh in these letters might therefore be of a later date than those in plaque two. ${ }^{50} \mathrm{It}$ is notable that the triangular head of the yodh is found mainly in the first half of the

45 'Die kriegerischen Darstellungen werden teilweise mit der Eroberung Judas unter Sanherib 701 in Vebindung gebracht (Naveh, dann bes. Lemarie; Mittmann)' (Renz, Handbuch 1, 243). For other opinions see W.W. Hallo \& K.L. Younger, Jr., The Context of Scripture: Volume II: Monumental Inscriptions from the Biblical World (Leiden: Brill, 2000), 179-80.

46 Cf. Renz type ' $p$ ' dated to the eighth and beginning of the seventh century (Renz, Handbuch 2/1, 141-43).

47 Cf. Barkay, 'Priestly Benediction', 172. However, the tendency to drop the lower horizontal stroke is not present in the bullae as presented by Avigad (Avigad, Hebrew Bullae from the time of Jeremiah: Remnants of a Burnt Archive (Jerusalem: Israel Exploration Society, 1986), 114; cf. Avigad \& Sass, Corpus, 44]. The archive has been ascribed to the late seventh - early sixth century (Avigad, Hebrew Bullae, 130). Thus it is difficult to attach much importance to this argument.

48 Cf. Renz, Handbuch 3, Tf. 14 Jer (8):30, Tf. 17 Seb (8):1, Tf.19 BLay (7):2, Tf. 22 Jer (7):2?, cf. however Renz, Handbuch 3, Tf. 27 MHas (7):1.

49 Yardeni, 'Remarks', 180.

50 Yardeni, 'Remarks', 182. The yodh on plaque one 1. 4 is unclear. It is difficult to say if the lower horizontal stroke is absent, invisible or follows the trace of the previous letter, a beth. 
seventh century [Z]. ${ }^{51}$ No such triangular yodh seems to be found on plaque one. Tentatively we suggest a date between 725 and $650 \mathrm{BC}$ for the second plaque. The evidence for the first plaque is inconclusive, but a date as early as $700 \mathrm{BC}$ is possible for this letter.

The clearest kaph on plaque one (1. 12) has an almost horizontal stroke coming out of the long leg to the left with an upward slant and a smaller stroke downwards from the middle of the horizontal stroke, instead of a smaller stroke upwards $\left.[>\rangle^{\prime}\right]^{52}$ This shape is found from the last quarter of the eighth century to the first half of the seventh..$^{53}$ Some have argued that the kaph in line 9 of plaque one has a $Y$ formed end of the horizontal stroke [y]. According to Barkay, this kind of letter has been found on a seventh century seal, but it has also been linked to Arad Ostracon no. 24, line 14, which Renz dates to the beginning of the sixth century. ${ }^{54}$ This letter might indicate a later date. However, it is questionable whether this $Y$-shaped form is present on the silver plaque. There are signs of an extended stroke downwards from the horizontal one, making this letter similar to the kaph in line 12. The horizontal stroke is slightly curved upwards $\left[E^{y}\right]$. In line sixteen of plaque one the kaph has a clear stroke pointing downwards to the left from the horizontal stroke [ 7 ]. However, it must be admitted that the horizontal stroke is broken into two lines at the tip of this small down-stroke. This might be due to poor skill of the writer and/or the small size of the letters. On the basis of the combined evidence, a date between 725 and $675 \mathrm{BC}$ might be suggested. There are several kaphs on plaque two. Each of them has a horizontal stroke slanted downwards to the left, with a new stroke upwards in the middle or near the tip of the horizontal stroke. Sometimes this new upstroke crosses the horizontal stroke. The closest parallels to this are found in the seventh century. 55

51 Cf. Barkay, 'Priestly Benediction', 172, Renz, Handbuch 3, Tf. 20 [Gar (7):1], Tf. 22 [Jer (7):2], Tf. 24 [Mur (7):1]. On Jer (7):2 see note 61 (below).

52 Cf. Barkay, 'Priestly Benediction', 172. This form is not found in the bullae of Avigad (Avigad, Hebrew Bullae, 114, cf. Avigad \& Sass, Corpus, 44). It is probably earlier than these.

53 Renz, Handbuch 3, Tf. 11 Arad (8):40, Tf. 19 BLay (7):1, Tf. 20 Gar (7):1 [cf. Mas (7):1]. Cf. also Phoenician or Aramaic seals from late eighth/early seventh century (Avigad \& Sass, Corpus, 411, no. 1087, [1089], cf. p. 410, no. 1086, p. 412 , no. 1090,1091$)$.

54 Renz, Handbuch 1, 389.

55 Parallels with respect to the head are found from the seventh century onwards: MHas (7):1, Arad (7):38, Gem (7):3 and Mur (7):1. A similar form is found in Sam (8):3. Most frequently the upstroke does not cross the horizontal stroke, but starts 
There are several examples of the letter lamedh on the amulets [1. - ]. They have long down strokes, a tendency particularly usual in the eighth and seventh centuries. All of these letters seems to have a slight bend in the down stroke (rounded towards the right), a tendency seen from the middle of the eighth century onwards. ${ }^{56}$

The shin-formed head of the mem on plaque one seems to have been written in two strokes, both similar to a $v$. The right leg of the left $v$ touches the middle of the left leg in the second $v$, and the right leg of the second $v$ touches the downstroke below its top. Thus the letter seems to have been written in three strokes [4/y. Renz describes this variant of the letter as a transitional form occurring by the end of the eighth century. ${ }^{57}$ The elements described above seem to agree with a date in the second half of the eighth century. ${ }^{58}$ Renz has no examples of such a character from the seventh century onwards. ${ }^{59}$ Furthermore, in the seventh century the right shoulder of the letter drops down $[\xi]$, and towards the end of the century the down stroke is shortened [ $y$ ]. The head of the mem on the second plaque might have been written in one stroke and is more difficult to date. However, the downstroke is particularly long and curves around the following resh.

There is no clear nun on plaque one. There is a possible one in line 13 and a very probable but nearly invisible one in line 18 . If the former is a nun [ 4], it is very similar to the mem described above. On plaque two the nun has a relatively large head, and a very long downstroke [y]. The clearest and most certain nun in line 9 has a curved head and a clear shoulder. A similar letter is found in Kom (8):6. The

in the middle of it or towards its left tip. The downstroke is longer than in many of the parallels, indicating that it may be older.

56 Renz, Handbuch 2/1, 167.

57 'Kann so die Mitte des 8. Jhdts. mit dem Eindringen kursiver Formen als eine erste neue Epoche bezeichnet werden, beginnt ab dem Ende des Jhdts. eine neue Tendenz in dem der Kopf des Mem zu Unregelmäßigkeit tendiert ... Die symmetrische $S$-form des Kopfes wird auch dadurch aufgeweicht, daß der Kopf aus zwei $v$-förmigen Winkeln zusammengesetzt wird, von denen der linke den rechten nicht oben, sondern in der Mitte seines linke Stiches triff' (Renz, Handbuch 2/1, 172-73).

58 For parallels to the left end of the $w$-formed head touching the downstroke below the top, see Renz, Handbuch 3, Tf. $8 \mathrm{Haz}$ (8):2, Tf. 9 Sam (8):6, Tf. $14 \mathrm{Jer}$ (8):33. The two first are from the third quarter of the eighth century $\mathrm{BC}$ and the third is from the fourth quarter of the eighth century BC. For letters with the left $v$ touching below the top of the left stroke in the right $v$, see Renz, Handbuch 3, Tf. 6 Sam (8):2, Tf. 8 Haz (8):2, Tf. 10 Sam (8):10, Tf. 13 EGed (8):2, Tf. 16 Lak (8):2. All examples are from the eighth century.

59 Renz, Handbuch 3, Tf. 19-33. 
possible nun in line 2 has a $v$-formed head. A very similar head is found in Jer (7):18. This form was in use in the period 750-675 BC.60 Both these letters have a wider opening of the head pointing more upwards than to the right. Again the long downstrokes indicate the relatively high age of the letters.

The samekh on the first plaque lacks the end curve of the lowest horizontal stroke that appears in the eighth century and is consistently found from the middle of the seventh century ${ }^{61}$ This is one of the clear letters and it indicates a date before the middle of the seventh century.

Of the three possible occurrences of the letter ayin, only one is fairly certain (pl. 11.10 ; cf. 1.8 and pl. 21.4 ). The letter in line 10 is round with a tip on the upper left side, indicating that the writer started and ended the letter at this spot [ $\triangle]$ ]. Renz describes this form primarily in the period between $725-600 \mathrm{BC}$, but earlier examples exist. ${ }^{62}$ The two other examples of this letter were drawn in two strokes, but the lower part is somewhat rounded [ 99 ]. The reason for this might have been that the letter started at the top and was not finished by the scribe in the first attempt. Thus the scribe had to start a new stroke to finish the letter. Similar letters from the end of the eighth century have been found (Kom (8):9). ${ }^{63}$

The shape of the pe on plaque two (1.9) is inconclusive. However, we have found only two instances of this letter with the short horizontal stroke curved downwards in the same direction as on this amulet [9] (Nim (8):1, Jer (7):1).64 The head of the letter is

60 Renz category ' $k$ ' (Renz, Handbuch 2/1,176).

61 So Barkay, 'Priestly Benediction', 173; cf. Renz, Handbuch 3, Tf. 1-22; cf. also Tf. 23-33 and Avigad \& Sass, Corpus, 44. A similar letter is found on a seal belonging to Samak (Avigad \& Sass, Corpus, 132, no. 282). The picture on the seal suggests a date before the reform of Josiah (Avigad \& Sass, Corpus, 45-46). A similar letter without the bend is found in a grave inscription (Jer (7):2) described by N. Avigad ('The Epitaph of a Royal Steward from Siloam Village', Israel Exploration Journal Reader [vol. 2, ed. H.M. Orlinsky, New York: Ktav, 1981], 704, 708) and dated to about the same time as the Siloam inscription (700) or to the first part of the seventh century. Avigad suggests that the inscription is related to 'Shebnah who is over the house' (Is. 22:15-16) belonging to the time of Hezekiah (Avigad, 'Epitaph', 151).

62 Renz type 'c' (Renz, Handbuch 2/1, 185); Renz also draws a parallel to type 'd', a form that existed in the 6th century. However, this type is not rounded to the same degree. It has three clear corners and one rounded line (Renz, Handbuch 1, 452).

63 Renz, Handbuch 3, Tf. 16.

64 Cf. Renz, Handbuch 3, Tf. 9, 22. 
somewhat similar to the earlier form with a round head. This form is found up to the end of the eighth century. ${ }^{65}$

There are multiple examples of the letter resh on the amulets. All of these have triangular heads $4 \& 4$, and some have very long vertical legs $[4$ (e.g. pl. 1, 1.14). The legs suggest a date in the eighth or the first part of the seventh century. There is great variation in the form of the head. In some cases they are open, in others they are flattened (cf. BLay (7):4,6,7, Gib (7):1).

On the first plaque the letter shin, with a shape resembling a $w$, has to various degrees slightly longer right and left strokes, compared with the two middle strokes. Thus the right and left strokes reach higher upwards than the two that meet in the middle [W]. This development is seen in the period from the end of the eighth to the beginning of the seventh century. ${ }^{66}$ On the second plaque the left stroke continues downwards, passing the end of the middle stroke (i.e. the middle left stroke) $\left[X^{+}\right]$. This tendency is seen in the second half of the eighth century and the first half of the seventh. 67

Based on the material presented above, a date around 725-650 BC seems reasonable for the first silver plaque, and a date by the turn of the century quite probable. ${ }^{68}$ As we have seen, the archaeological evidence allows such a conclusion.

This palaeographic dating is not dependent on a few letters, but on a combined evaluation of all the letters together. The parallels

65 Renz type 'a' and 'b' (Renz, Handbuch 2/1, 188).

66 So Renz, Handbuch 2/1, 204. See esp. the first silver amulet, plaque one line eight. See, however, bulla 161 in Avigad, Hebrew Bullae, 102, which he dates to the last quarter of the seventh century or later (Avigad, Hebrew Bullae, 113). However, this bulla (Avigad \& Sass, Corpus, 234, no 633) is without known origin (Avigad \& Sass, Corpus, 169-70; cf. 548). Additionally, the letter shin is written with curved lines on this bulla.

67 Renz, Handbuch 3, Tf. 9 Haz (8):7, Tf. 18 Imlk (8):1, Tf. 19 BLay (7):1,3. In table 19 Renz has such a $w$-shaped letter of the BLay 7:1 inscription in the column of the letter taw. In the grave inscription, however, this letter is part of the city name Jerusalem, thus representing the letter between $r$ and $l$, which is a shin. Renz probably misplaced the letter. See also the seal of Manasseh, son of the king (Avigad \& Sass, Corpus, 55 , no. 16 ; cf. p. 62 , no. 34 , p. 74 , no. 73 , p. 76 , no. 80 , p. 85 , no. 112 , p. 113 , no. 206 , p. 115 , no. 215 , p. 119 , no. 231 ). This seal prolongs the right line of the two $v$-formed parts of the letter, but it should be mentioned that the seal is inverted. A letter like shin, which looks almost the same if seen through a mirror, could easily be written in the same form on a seal and on other material. The seal is early, containing a two-winged beetle, thus probably earlier than the reform of Josiah. It is possible that it belonged to Manasseh, the son of Hezekiah, who followed his father on the throne in 696 BC (cf. Avigad \& Sass, Corpus, 55, 45-46).

68 Concerning such a date for Bet Layy see Renz, Handbuch 1, 243. 
between the silver amulets, the grave inscription in Khirbet Bet Layy, and the jar handle inscription from Gibeon, have been noted by many. ${ }^{69}$ These items have been variously dated, but a date around 700 $\mathrm{BC}$ is possible. ${ }^{70}$ These parallels are important since the technique involved is more similar to that used in the inscriptions on the amulets than to that for inscriptions made by pen and ink. Based on palaeographic evidence we suggest a date around $700 \mathrm{BC}$ for the first amulet, and a somewhat later date for the second. ${ }^{71}$

\section{'Belonging to Isaiah'}

Barkay has noted an interesting feature: on the reverse side of the second amulet the inscription לישעהו (belonging to Isaiah) has been identified, including the name Isaiah (ישעיחו), but without the second $Y .{ }^{72}$ One cannot be certain about this inscription, as the letters are difficult to read..$^{73}$ However, if the reading is correct, the second silver amulet belonged to a prominent person called Isaiah. The most prominent person named Isaiah in the Bible is the prophet. He

69 'In general, the script on both plaques has much affinity with the script of the seals and bullae from the end of the first temple period, and also with the script of the jar handles from Gibeon and with the script of the cave inscriptions from Khirbet Bet Lei' (Yardeni, 'Remarks', 178; cf. Barkay, 'Priestly Benediction', 169). Renz admits that there are close parallels between the silver amulets and the inscriptions from Bet Layy (Handbuch 1, 449).

70 The date of the Bet Layy inscriptions has been variously assessed, but one at the end of the eighth or beginning of the seventh century seems probable (Renz, Handbuch 1, 242-44, 3: Tf. 19; Barkay, 'Priestly Benediction', 169, n. 15). The jar handle from Gibeon has also been variously dated. However, a date in the first part of the seventh century is arguable (Renz, Handbuch 1, 257-58; Barkay, 'Priestly Benediction', 169, n. 15). 'It seems that the low chronology, i.e., 6th century B.C.E. for the inscriptions from Khirbet Beit-Lei and Gibeon (Cross 1962b; 1970:299-306) was established when the lmlk handles were still dated to the days of King Josiah, i.e. to the 7th century B.C.E. (Lance 1971). These low dates were undoubtedly influenced by the Albright School and its followers, who dated the destruction of Lachish level III and related strata and their ceramic assemblages to 597 B.C.E. On the other hand, scholars who accept the 701 B.C.E. date for the destruction of Lachish level III also arrived at higher dates for the inscriptions, i.e., ca. 700 B.C.E. (See Avigad 1959:132; Lemaire 1976:563-565)' (Barkay, 'Priestly Benediction', 169, n. 15). Renz (Handbuch 1, 218) dates the bt lmlk before 701 .

71 The rest of this article is based on the assumption that the first plaque was inscribed about $700 \mathrm{BC}$. If the plaque was inscribed about $600 \mathrm{BC}$, as suggested by Barkay and Yardeni, most of the other dates suggested change accordingly.

72 Barkay, 'Priestly Benediction', 167-68.

73 The letters line up poorly. This might be due to their inscription on the amulet after it had been rolled (cf. Barkay, 'Priestly Benediction', 168). A similar inscription with the name Isaiah on a jar, from the end of the eighth-beginning of the seventh century, has been identified in Jerusalem (Jer (7):29; Renz, Handbuch 3, Tf. XXXIII, 2). 
ministered in Jerusalem during the reign of Uzziah, Jotham, Ahaz, and Hezekiah (Is. 1:1). Hezekiah died about 686 BC. ${ }^{74}$ The name Isaiah is known to have been used by other people as well (e.g. the sons of Hilqiyahu, Samak and "Amalyahu). ${ }^{75}$ For a reliable identification with the biblical Isaiah, it would be necessary to have the name of his father as well (i.e. Amoz, Is. 2:1) ${ }^{76}$ However, the silver amulet does not provide this information. ${ }^{77}$

\section{The Priestly Blessing}

The text below is that of Yardeni: ${ }^{78}$

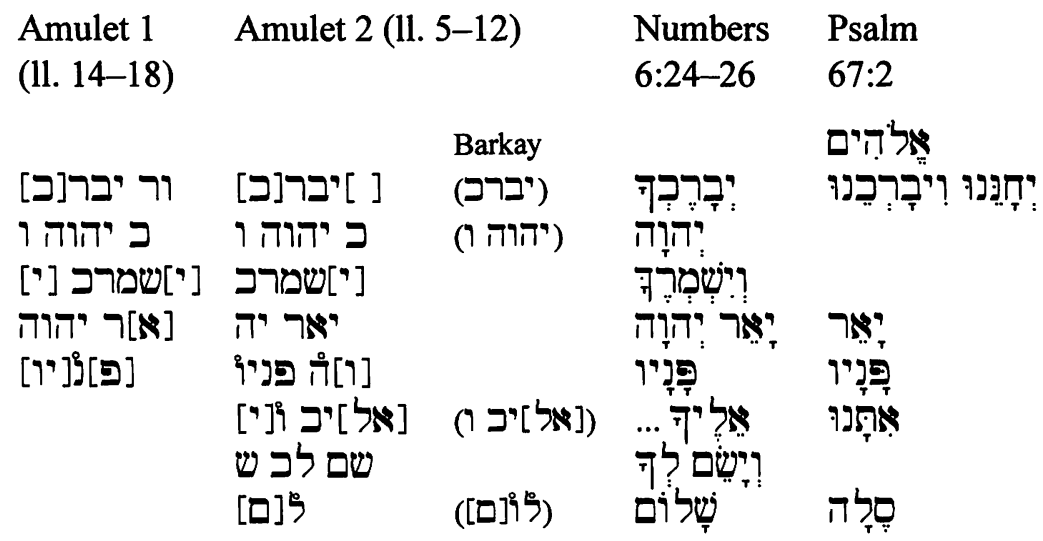

Barkay discusses whether MT or the Ketef Hinnom amulets include the earliest version of the priestly benediction (Nu. 6:24-26). He concluded: 'An accepted principle of research holds that a shorter text predates any expanded version. However, in our case the complete and consolidated structure of the Massoretic Priestly Benediction indicates that it is the earlier one.' 79 The texts on both amulets are clearly shorter than the MT, but it is only from the second amulet that

\footnotetext{
74 Isaiah is thought to have died during the reign of Manasseh (d. ca. $641 \mathrm{BC}$ ).

75 Avigad \& Sass, Corpus, 114-15, seals 212-15. See also Jer (7):29 (cf. Renz, Handbuch 3, Tf. XXXIII, 2). See also 1 Chronicles 25:15.

76 The minimum condition for the identification of the name on a bulla with a biblical person is normally a match of the name of the father and the son. Secondly the date of the bulla must be compatible with the biblical record. However, there is no legible reference to a father on the second silver amulet.

77 It is impossible to make any firm argument on this basis, but identification with the prophet Isaiah fits with our palaeographic dating of the text.

78 Yardeni, 'Remarks', 178.

79 Barkay, 'Priestly Benediction', 177.
} 
we can know that the original was shorter than MT, as the number of letters in the space between the first and second parts is too large to fit in.

The appearance of two amulets with the same text indicates that this text must have been important and standardised at the time of inscription. It should be remembered that two different hands inscribed the two amulets, probably at different times and places. The correspondence between the two amulets and the first five lines of Numbers 6:24-26 speaks for a constant text form:

Die verschiedenen Fassungen der Amulette lassen eher vermuten, daß der Segen in sein vollständige Form bereits vorhanden war und daß daraus für den apotropäischen Text eines Amuletts verschiedene Kurzformen hergestellt werden konnten ... 80

It is uncertain whether this conclusion goes far enough. A comparison of Numbers 6:24-26 with the 32 legible characters on the second amulet shows full correspondence of all these characters in the parallel sections of the two texts. ${ }^{81}$ A comparison of Numbers 6:24-26 with the first amulet gives a similar conclusion: all of the 19 legible letters in this part of the amulet seem to correspond with the MT. ${ }^{82}$ Despite the shorter form of the second amulet, it is difficult to believe that such an exact correspondence between the texts is probable if the texts were not written down.

The parallel between the second amulet and MT includes the use of matres lectionis. Barkay has pointed out that the mater lectionis in the word אליך (plaque $2,1.10$ ) $^{83}$ is absent in some early texts. ${ }^{84} \mathrm{~A}$ similar observation has been made with reference to the word שלום

80 Renz, Handbuch 1, 448. Renz further argues that the similarity between the MT and the amulets, including the plene writing of some vowels, indicates a post-exilic date (p. 448).

81 Yardeni, 'Remarks', 178, Barkay has two more legible characters bringing the total to 34 of 34 letters (Barkay, 'Priestly Benediction', 159).

82 Yardeni, 'Remarks', 178, Barkay, 'Priestly Benediction', 159).

83 Yardeni ('remarks', 178) and Barkay ('Priestly Benediction', 167) agrees about this reading. Yodh is the first legible letter in the word.

84 'Ostracon 3:9 from Arad contains the letters 7 , which Aharoni reads as אל (Aharoni 1981:17-18). An unvocalised spelling in which the yodh does not appear as a mater lectionis is also found in the Lachish Letters, where אל הם written instead of אלהים (No. 6:9) (Lachish I:105). A similar spelling also appears several times in MT (e.g. Ge. 19:6, אלדהם, while the spelling אלהים appears in v. 10)' (Barkay, 'Priestly Benediction', 165; cf. Y. Aharoni \& J. Naveh, Arad Inscriptions [Tr. J. Ben-Or, Jerusalem: Israel Exploration Society, 1981], 17-18). 
on plaque two. ${ }^{85}$ However, both the MT and the second amulet use matres lectionis for these two words. ${ }^{86}$ Earlier studies have shown that the use and non-use of matres lectionis were inconsistent in early Hebrew and Aramaic, ${ }^{87}$ making the consistency between the MT and the amulets somewhat surprising. ${ }^{88}$ Other notable parallels are the

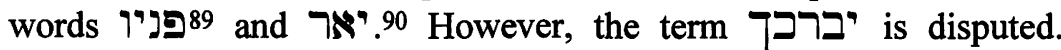
Barkay thinks that the word lacks the last $\supset$ on both plaques, whereas Yardeni, has a double kaph (כך-) at the end of the word.91 The

85 'This line is almost completely destroyed, with only a few upper strokes of the letters remaining. Three letters may be reconstructed, more through analogy to the biblical text than on the basis of visible vestiges. Thus, the reading we suggest is [a] ל. If this reconstruction is correct, waw would have served as a vowel in the middle of the word, to be read as $\hat{o}$. In Hebrew epigraphy, the word שלם, 'peace', appears in the Lachish Letters and Arad Ostraca, invariably without waw. However, waw does appear as a vowel in inscriptions dating to the end of the Iron Age as, for example, the inscription מרמות from Arad Ostracon $50 \ldots$ and in the 8th century seal impressions of למלך סוכה (Barkay, 'Priestly Benediction', 165; cf. also Renz, Handbuch 2, 234).

86 Yardeni disagrees. She indicates that only one letter can be seen in this line (Yardeni, 'Remarks', 178).

87 A.R. Millard, 'Variable Spelling in Hebrew and Other Ancient Texts', JTS 42 (1991) 106-115.

88 It is difficult to know when the biblical text went through a change from defective to plene writing. The present state of the MT combines the two forms, forming inconsistent spelling (Millard, 'Variable Spelling', 108). The texts from Qumran are generally plene, but far from consistent. 'The arbitrary element in biblical Hebrew spelling, the inconsistency in the inclusion and exclusion of vowel-letters ... can now be seen to be part of a common feature of ancient near eastern scribal practice' (pp. 114-15). When variation in spelling is the rule of the day, then continuity in spelling is more significant.

89 'The spelling of the פניו-with the letter yodh-is also noteworthy, both here and in MT. The yodh in our inscription is clear and unmistakable. The linguistic form פניו פניהו developed from is the written form of the contracted diphthong. By way of contrast, the yodh is omitted in the Lachish Letters ... Similarly, the spelling אלו אל י איו in the letter from Mesad Hashayahu ... and the particle רעי רעו or in the Siloam Inscription' (Barkay, 'Priestly Benediction', 165).

90 '... the spelling of the $\$$ ' in both plaques is identical to the spelling in MT (Nu. 6:25; Ps. 67:2). In the Samaritan Bible and in the Dead Sea Scrolls (Manual of Discipline-1QS. II:3), the spelling is ריא" (Barkay, 'Priestly Benediction', 158). Thus in this case the mater lectionis is absent from both the amulets and the MT.

91 On plaque two Barkay finds a single $\sqsupset$ (Barkay, 'Priestly Benediction', 162; Barkay, 'Excavations', 104). However, Yardeni indicates that there is room for an extra $\supset$ at the beginning of 1.6 [Yardeni, 'Remarks', 178-79; cf. O. Keel \& C. Uehlinger, Göttinnen, Götter und Gottessymbole: neue Erkenntnisse zur Religionsgeschichte Kanaans und Israels aufgrund bislang unterschlossener ikonographischer Quellen [Freiburg, Basel \& Wien: Herder, 1992], 418). In plaque one Barkay argues that there is no room for a $\sqsupset$ at the end of 1.14 , whereas Yardeni indicates the opposite (Barkay, 'Priestly Benediction', 152, 157; Barkay, 
continuity in spelling between plaque two and the MT speaks for a common written source. The absence of some words in the text might be explained by homoioteleuton or as a conscious shortening of the text. ${ }^{92}$ The evidence from plaque two is not contradicted by plaque one, although this plaque has less corresponding text and lacks most of the important parallels noted above.

The use of matres lectionis on the second amulet might pose a problem for the early dating of this amulet:

A cursory examination of MT shows that its spelling does not fit into any phase of pre-Exilic spelling, which even in the latest materials shows only sporadic use of internal matres lectionis. On the contrary, MT exhibits consistent use of internal matres lectionis for $\bar{u}$ and $i$ and the contracted diphthongs $a w$ and $a y$ ( $\hat{o}$ and $\hat{e}$ respectively). The representation of $o$ varies considerably (i.e., sometimes the waw is used, sometimes not), while $\bar{a}$ and $\bar{e}$ are not represented by vowel letters. There is no indication of short vowels. ${ }^{93}$

However, this is not an absolute criterion, as matres lectionis were introduced into Hebrew writing in the ninth and eighth centuries, at first at the end of words, later in the middle of words. ${ }^{94}$ The development of the matres lectionis in Aramaic and Hebrew is even seen earlier than this. They are found in the middle of words in Aramaic inscriptions dated as early as the eleventh century $\mathrm{BC}, 95$ and

'Excavations', 104; Yardeni, 'Remarks', 178-79; Keel \& Uehlinger, Göttinnen, 418).

92 So Barkay, 'Priestly Benediction', 166.

93 Freedmann, 'Massoretic Text', 199-200.

94 Cf. Freedmann, 'Massoretic Text', 197, F.M. Cross \& D.N. Freedman, Early Hebrew Orthography: A Study of the Epigraphic Evidence (New Haven, CT: American Oriental Society, 1952), 2. Avigad names an example from about 700 BC where the plene writing includes a medial waw (קרור). With reference to plene writing Avigad argues as follows: 'On the other hand it may be argued against this synchronism that the writing of the Siloam inscription is defective throughout, whereas in ours the word is written in plene' (Avigad, 'Epitaph', 704). Nevertheless, Avigad dates the text to about 700 due to palaeographic evidence, and he also speculates whether the tomb belonged to a certain 'Shebna who is over the house' that Isaiah rebukes (Is. 22:15-16) (Avigad, 'Epitaph', 151-52; cf. pp. 144-45; Millard, 'Variable Spelling', 107; Barkay, 'Priestly Benediction', 160. Cf. also Jer (7):2,2 in Renz, Handbuch 3, 21, dated to the first part of the seventh century). Twice Ostracon 40 from Arad (ca. 825-800 BC) uses the plene writing of the term man (שישישי 1. 1. 8) (Renz, Handbuch 1, 147; cf. Millard, 'Variable Spelling', 107).

95 'In the earliest Aramaic and Hebrew inscriptions matres lectionis were used ... the idea of matres lectionis was known as early as the thirteenth century B.C. The North Canaanites in Ugarit used yod in certain instances to designate $i$; they also introduced the supplementary letters ' $u$ and ' $i$ and turned the original 'alef into ' $a$ ' [Naveh, Early History of the Alphabet: An Introduction to West Semitic Epigraphy and Palaeography (Jerusalem: Magnes; Leiden: Brill, 1982), 183]. 'Recently a 
they were probably borrowed into Hebrew texts from other Semitic languages. 96

The inclusion of the same matres lectionis as in MT and other similarities between these texts confirms that there was a common source behind the two amulets and MT. It seems unlikely that the amulets represent the archetype of MT. Amulets are more likely to adhere to existing traditions than to form new ones. ${ }^{97}$ Therefore it is probable that the common archetype was available at the time of the inscription..$^{98}$ The implication of this is that the author of the second amulet shortened the text, either by accident (homoioteleuton) or purposely. Thus we agree with Barkay that the Masoretic version of

relatively long bilingual (Akkadian-Aramaic) monumental inscription was found at Tell Fakhariyah in Syria. According to the information gathered so far on this unpublished inscription, it appears to belong to the eleventh century B.C. and the Aramaic text has not only final but also medial matres lectionis' (Naveh, Early History, 89, n. 52). Millard and Bordreuil date the statue to the middle of the ninth century (A.R. Millard \& P. Bordeuil, 'A Statue from Syria with Assyrian and Aramaic Inscriptions', Biblical Archaeologist [1982] 136-40). However, they admit that some of the letters have no parallels after the 11 th and 10th centuries (p. 140). Based on palaeographic evaluation of the text Naveh has maintained an 11th century date for this inscription, and he maintains that plene writing was used as early as the thirteenth century in Ugarit (J. Naveh, 'Proto Cananite, Archaic Greek and the Script of the Aramaic Text on the Tell Fakhariyah Statue', Ancient Israelite Religion. Essays in Honor of Frank Moore Cross [ed. P.D. Miller, Philadelphia: Fortress, 1987], 107). Naveh argues as follows: 'The authors of the editio princeps were wholly aware of the palaeographic features of the Fakhariyah inscription. However, as they preferred to base their conclusions on other criteria, they tried to attenuate the palaeographic evidence ...' (Naveh, 'Proto Cananite', 103). Based on later Greek inscriptions Millard maintains a date in the ninth century (A.R. Millard, 'The Tell Fekheriyeh Inscriptions', Biblical Archaeology Today, 1990: Proceedings of the Second International Congress on Biblical Archaeology: Jerusalem, June-July 1990 (ed. A. Biran \& J. Aviram, Jerusalem: Israel Exploration Society, Israel Academy of Sciences and Humanities, 1990), 518.

96 'Since the system of matres lectionis was not used in Hebrew before the 9th century, and since that system is substantially the same as the one used in Aramaic from the beginning of that century (if not earlier), and in Moabite from the middle of the 9th century (at the latest), it can hardly be doubted that this system was borrowed by the Israelites from the Aramaeans during the course of the 9th century B.C. Because of the sharp break in Hebrew orthographic practice between the 10th and succeeding centuries, there is no possibility that the Hebrew system of vowel letters was indigenous, arising gradually out of an accumulation of historical spellings' [Cross \& Freedman, Early Hebrew Orthography, 57].

97 This is based on the assumption that incidental parts of amulets normally would remain incidental rather than form a new tradition that subsequently is transmitted into longer texts.

98 Barkay has a third solution. He argues that several versions of the benediction existed before the inscription of the amulets (Barkay, 'Priestly Benediction', 177). 
the priestly benediction ' $\ldots$ is the most ancient, and it influenced the Ketef Hinnom inscriptions which are abbreviated versions. ${ }^{99}$

\section{Kuntillet 'Ajrud}

Another text, with a similar blessing formula, is in the one from Kuntillet 'Ajrud. There are several differences between these two texts, but at least they include the 'bless and keep you' formula: 100

Nu. 6:24-26

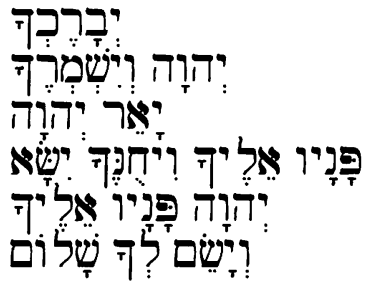

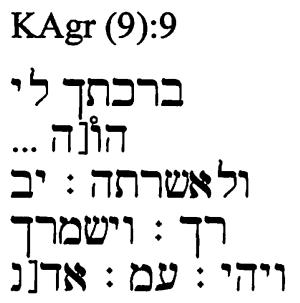

This text clearly refers to Yahweh and his consort. The text was found in Sinai, at a place inhabited for a short period of time by priests from Samaria belonging to the northern kingdom of Israel. The name of king Joash (801-786) is found in these texts. ${ }^{101}$ The relationship between Yahweh and his Asherah seems to be paralleled in the condemnation of syncretism in 1 Kings 13:6, a text which refers to the father of Joash. The biblical picture given of Jehoahaz is clearly syncretistic, and the picture of Joash is no different (1 Ki. 13:11). The interesting element is the fact that this text from Kuntillet 'Ajrud has been dated ca. $800 \mathrm{BC}^{102}$ It must be noted that aside from the Kuntillet 'Ajrud texts Asherah is little attested in extrabiblical texts

99 Barkay, 'Priestly Benediction', 177. Barkay further argues that the inclusion of the term Swd in plaque one is indication of the pre-exilic origin of the Priestly code (Barkay, 'Priestly Benediction', 179).

${ }_{100}$ Renz, Handbuch 3, 4; cf. Barkay, 'Priestly Benediction', 158. 'A similar combination appears in the 13th century B.C.E. Akkadian letter sent from Ugarit and uncovered at Aphek "... The gods of the land of Ugarit bless you and keep you"' (D.I. Owen, 'An Akkadian Letter from Ugarit at Tel Aphek', Tel Aviv 8 [1981] 4-11).

${ }_{101}$ Renz, Handbuch 1, 62, cf. ABD 4:197, col. 2.

102 Binger dates it to 836-797 BC (T. Binger, Asherah Goddesses in Ugarit, Israel and the Old Testament [JSOTSS 232; Sheffield: Sheffield Academic, 1997], 102, n. 32; cf. Renz, Handbuch 1, 60). 
after about $1000 \mathrm{BC}, 103$ being replaced by other goddesses such as Astarte and Anat. ${ }^{104}$

For those who date the Deuteronomistic History to the post-exilic period it must be puzzling that Asherahs are found in the pre-exilic Prophets (Is. 17:8, 27:9, Mi. 5:13, Je. 17:2; cf. Elijah 1 Ki. 18:19), but not in any exilic or post-exilic prophets, nor in any other OT books describing post-exilic times. ${ }^{105}$ The extrabiblical and biblical texts confirm that the Asherahs lost their importance before the end of the monarchy. ${ }^{106}$ The importance of this goddess to the Deuteronomistic History seems inexplicable in post-exilic times. The replacement of the Asherahs by other goddesses implies that texts using the older name are earlier than the exile.

\section{A Verse from Deuteronomy?}

The possible identification of another Pentateuchal text on the first amulet from Ketef Hinnom is extremely important. Barkay argued

\footnotetext{
${ }^{103}$ Renz gives the following Old Hebrew texts using the term Asherah: 'KAgr (9):6, 8, 2; 9,6; 10,2; $\operatorname{Kom}(8): 3,3$ ' (Renz, Handbuch 2/1, 91). Thus he has found no such extrabiblical Hebrew texts later than the eighth century $\mathrm{BC}$, or possibly the seventh century (cf. Binger, 'Asherah', 94).

104 'Im 1. Jtsd. erscheint Aschera neben Baal, evt. auf Grund einer allmählichen Verschmelzung der Göttinnen ' $n t$, 'trt und 't trtt, im AT, evt. auch im Phönizischen. In den althebr. Belegen wird Aschera Jahwe beigeordnet' (Renz, Handbuch 2, 92, cf. Binger, 'Asherah', 106, 111-13, 130-33). 'The goddess Asherah is no longer important in the first millennium B.C. ... Apart from statements in the OT, the only allusions to the goddess Asherah which we know come from the Arabian Peninsula ... Gradually, Asherah probably came to be identified with Astarte and Anat, who in turn had been united in one goddess as the Syrian Atorgatis' (De

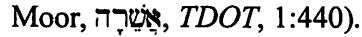

105 The term sise (in different grammatical forms) turns out the following texts: Ex. 34:13, Dt. 7:5, 12:3, 16:21, Jdg. 3:7, 6:25, 26, 28, 30, 1 Ki. 14:15, 23, 15:13, 16:33, 18:19, 2 Ki. 13:6, 17:10, 16, 18:4, 21:3, 7, 23:4, 6, 7, 14, 15, Is. 17:8, 27:9, Je. 17:2, Mi. 5:13, 2 Ch. 14:2, 15:16, 17:6, 19:3, 24:18, 31:1, 33:3, 19, 34:3, 4, 7.

106 'If we are to forward a possible explanation of what the "houses of Asherah" could be, my immediate association of ideas is the house shaped incense altars found within the area defined as "Israel" in this book. Many of those have decorations, including various animals and humanoid figures, probably goddesses. The only problem with this association is that most of these are from the Bronze Age or early Iron Age, whereas this text (i.e. $2 \mathrm{Ki} .23: 4,7$ ) can under no circumstance be earlier than the sixth century, and in all probability is much later than that' (Binger, 'Asherah', 118).
} 
that this amulet includes a passage from Deuteronomy 7:9.107 The parallel is shown below: 108

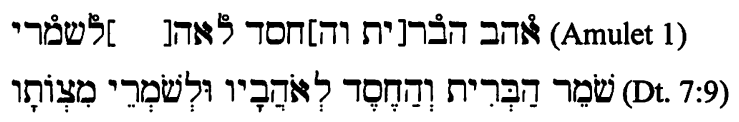

... [who] loves the covenan[t and] mercy for those who lo[ve him and] keep [his commandments] (amulet)

... who keeps the covenant and mercy for those who love him and keep his commandments (Dt. 7:9).

The terms love (amulet 1) and keep (Dt. 7:9) are common in Deuteronomy, and they are used in an almost synonymous fashion. Thus the variation between these two words is not unexpected. ${ }^{109}$ However, if the four consecutive words following the first one are parallel, as suggested above, this parallel is more than significant. Normally, three words are needed in order to establish a quotation. In this case there are two clear words, two prepositions, one article and two half words, altogether eighteen consonants $(6+6+5)$. Of 17 legible consonants, 14 are the same in the two texts. The parallel seems close enough to speak of a quotation. The variation amounts to the exchange of a whole word, rather than variation in spelling. The

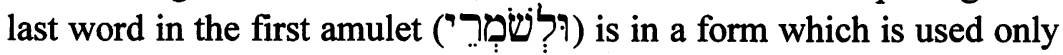
8 times in the OT (Qal participle active plural construct masculine

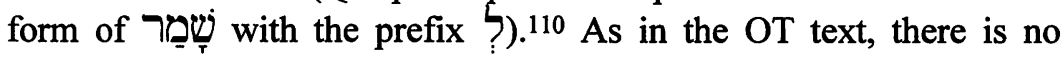
mater lectionis for the long $o$-sound. Deuteronomy 7:9 is taken from the frame of Deuteronomy, a text that has often been considered the youngest part of Deuteronomy. It could be argued that Deuteronomy 7:9 is part of a covenant formula that was in use prior to the compilation of Pentateuchal texts. However, just as in the case of the priestly blessing, the spelling is similar to that of MT. There is no mater lectionis in the last legible word on the amulet or in the parallel

${ }^{107}$ Barkay, 'Priestly Benediction', 155.

108 Barkay, 'Priestly Benediction', 159; 154-55. The circled letters are fairly uncertain, those in parentheses are added by Barkay. I have changed the status of the first aleph. There are clear traces of this letter, even though the horizontal strokes are invisible on the left side of the down stroke. I have also changed the status of the second aleph, as this letter is perfectly visible. The only problem seems to be its unusual form (discussed above). Apart from the lower horizontal stroke all the other strokes are visible. The mem has a clear downstroke, but lacks the shin-formed head. The first lamedh seems clear, even though some unnecessary strokes are found close to it. The down stroke of the second lamedh is barely visible, but the short tail is clear.

${ }^{109}$ It must be admitted, however, that the combination of the terms 'loving' and 'covenant' is not very common (Renz, Handbuch 1, 455, n. 1).

${ }^{110}$ Ex. 20:6, Dt. 5:10, 7:9, Ezk. 44:8, Ps. 103:18, 119:63, Dn. 9:4, Ne. 1:5. 
in the MT. Granted the brevity of the text, it is difficult to come to a firm conclusion about a written source for it. However, it should not be overlooked that this last word confirms the parallel use and nonuse of matres lectionis between MT and the amulets.

Granted the presence of two parallels to the Pentateuch, it seems reasonable that both the first amulet and the Pentateuchal texts are based on the same tradition. In principle these traditions could be taken over from liturgical texts or historical texts, either written or oral. We have argued above that the existence of two amulets with a similar text implies a standardised text form.

\section{Relationship between the Amulets and the Pentateuch}

Above we have argued that the priestly blessing and Deuteronomy 7:9 were introduced in the amulets from written sources that the amulets have in common with MT. The fundamental question is how it is possible that two parts of the Pentateuch are present in one amulet. Several different theories might account for this: 1) the two texts, Numbers 6:24-26 and Deuteronomy 7:9, were derived from two different and lost documents. These two documents were used separately by the person who inscribed the amulets $(A)$, and by the compiler or redactor of the Pentateuchal texts $(P), 2)$ the two texts were derived from one document by both $A$ and $P, 3) A$ derived the text from the work of $P$, or 4) $P$ derived the text from the amulets. As we have argued above, alternative 4 is not very likely. We are therefore left with three possible answers.

\section{One or Two Documents?}

Numbers 6:24-26 is a liturgical text. It is possible to think that such a liturgical element could have been implanted in a later text. If this were the case, the actual part of the liturgy had to be stable at the time when the amulets were made. The first part of the first amulet has the form of a covenant formula. Thus again it is possible to argue that this part of the covenant formula was in use before the rest of the text was formed. However, the combination of these two texts, the former with extraordinary correspondence in wording and spelling, the second with reasonable correspondence, is of importance. The question is: what is the probability that two persons $(A$ and $P$ ), who according to the theory lived some centuries apart, collected the same two texts 
from the same two documents? In this context it is important to evaluate the character of the first amulet. In addition to the priestly blessing there is at least one reference to the Tetragrammaton in it (1. 12 ; cf. 1. 1). It is reasonable to believe that this amulet was part of worship. Thus adherence to the covenant (11.4-5) should be interpreted in a religious rather than a secular sense, as reference to the covenant loyalty of Israelites (cf. Dt. 7:9). This is further underlined by the combined reference to covenant (ברית) and mercy (Tס), probably God's mercy. 111 The combination of the terms 'love' (אהב) and 'keep' (שמר) is typical of Deuteronomic language, making the formula fit well within Deuteronomic theology. The nature of the amulet makes it probable that the text was quoted from a source containing more text. Thus it is plausible that the source document was related to Deuteronomy in.a more profound sense. It is unlikely that the silver amulets give testimony to a united tradition, which later was split into different sources, and then united again into a single document such as the Pentateuch.

\section{The Extent of the Document}

It is impossible to make an absolute estimate of the extent of the source document used to produce the amulets. However, a short text is less likely to include multiple subjects and functions. The longer the text, the more complex its nature. The relationship between Deuteronomy 7:9 and Numbers 6:24-26 is not immediately obvious, as the first text could be termed covenantal and the second liturgical. Based on this, it is arguable that the source document for the amulets probably included more text than the elements used in the amulets. It seems probable that this document contained a longer section that included liturgical matters and a longer section with covenantal material. The text also had to contain elements that justified the inclusion of material of such different characters. It is difficult to argue that several authors used such a primary source document to produce sources that subsequently were united again into the Pentateuch. If the primary source was one, then it is more likely that a division into separate sources never happened. ${ }^{112}$

111 Zobel (Tֶ, TDOT V, 61) argues that the combination of these two concepts happened in the 'Post-Deuteronomistic period'. The text of the first amulet is too short to disprove this, but it certainly makes such a conclusion questionable

112 Naturally there is uncertainty concerning the obscure parts of the amulets, parts that we have not been able to read. The following argument is based on the current state of the discussion. 


\section{The Primary Source Document}

It is arguable that the contents of the amulets indicates a larger source document available to the person making the inscriptions on the first amulet about $700 \mathrm{BC}$, about the time of Sennacherib's campaign against Hezekiah, several generations before the reform of Josiah (ca. $621 \mathrm{BC}) .{ }^{113}$ This has considerable implications for the chronology of the Pentateuch.

The use of these texts in two amulets indicates that this source document must have played an important part in the cult, with the consequence that it was worthwhile to use it in amulets. It seems reasonable to suppose that a time span passed from its promulgation in the cult to the accidental incident that one person wrote down these words on amulets that were preserved for posterity.

\section{Conclusion}

Based on the evidence from Ketef Hinnom the following argumentation has been presented: 1) The presence of the priestly blessing in two amulets and MT with little variation in the text indicates a continuous written tradition before the inscription of the amulets (700-650 BC). 2) The presence of the two texts from the Pentateuch in one amulet speaks for a written tradition including these two texts prior to its inscription. 3) It seems likely that this written tradition was found in a unified document. 4) The inclusion of different kinds of material in one document indicates that the document must have been longer. 5) If the Pentateuchal texts were inscribed on the amulets because of the importance of the archetype, then a time span may be needed for the text to become influential. 6) The accidental character of an amulet and the sparse material from this time suggest that the amulets are not the earliest use of this text. 7) It may be concluded that at least important constituents of two strands of material in the Pentateuch are likely to have been found together before Josiah's reform, or even as early as Manasseh.

The argumentation here is dependent on our archaeological and palaeographic dating of the amulets. If the amulets be dated about 600 $\mathrm{BC}$, as suggested by other authors, the other dates would have to be amended accordingly. However, this is still the pre-exilic period and

${ }^{113}$ Cf. Harrison, Introduction, 191, 804. 
consequently the challenge to an exilic or post-exilic date of the combination of Pentateuchal sources is maintained.

\section{Appendix: The texts of the Ketef Hinnom silver amulets ${ }^{114}$}

Amulet 1

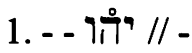

2. - ....

3. - - - -

4.

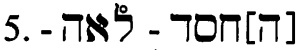

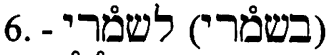

7. - - - - - - - - - -

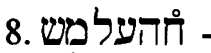

בה • • המכל • (9חעל

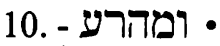

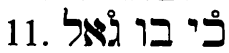

הכי יהוה • 12.

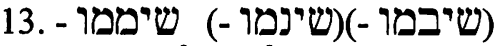

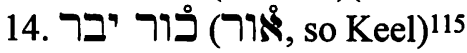

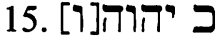

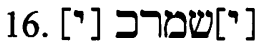

17.17. אִּר ייהוה

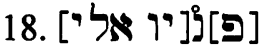

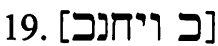

Amulet 2

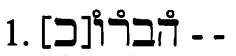

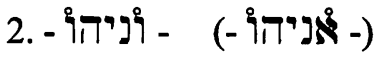

3. [1] ר-

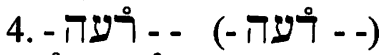

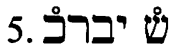

6.

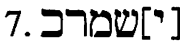

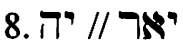

9.

10.

11. שׁמ לכ שיכ שי

12. [מุ

13. . . . .

14. - • - -

15. - - - -

16. - . . -

17. - ว - กำ

18. - . . -

114 Following Barkay, 'Priestly Benediction', 159, 167 (cf. above note 108).

115 Keel \& Uehlinger, Göttinnen, 417-23. 


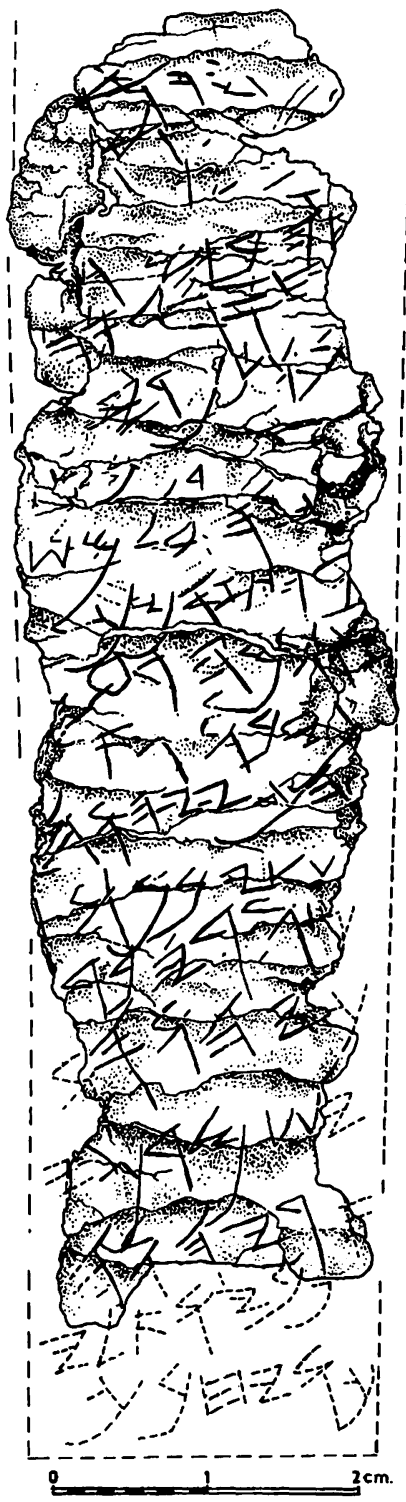

Ketef Hinnom Plaque I

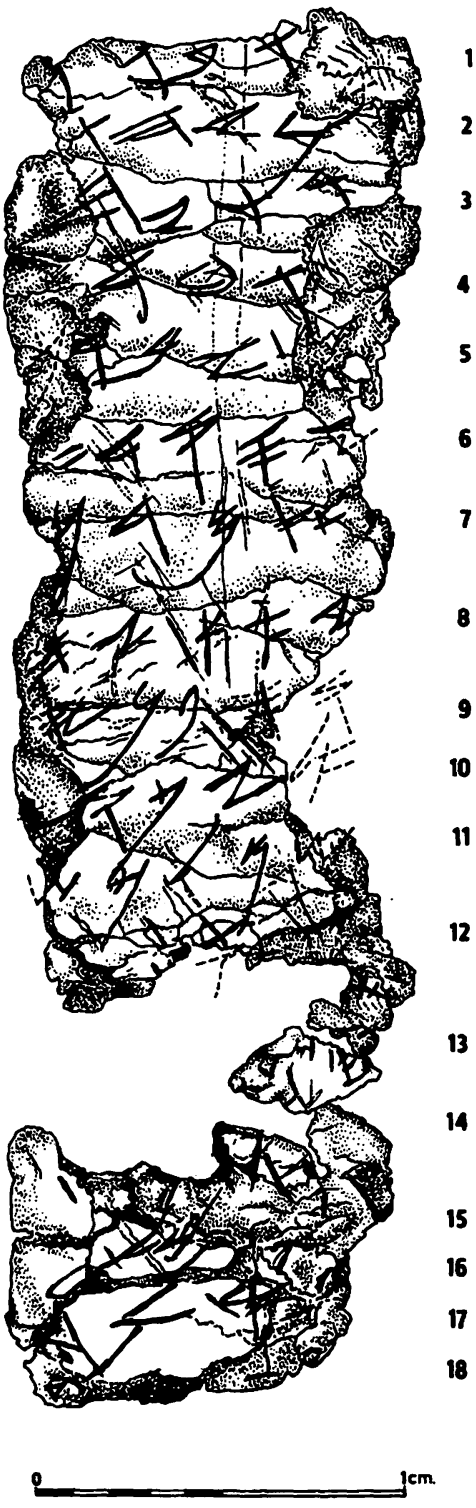

Ketef Hinnom Plaque II

Reproduced with kind permission of Dr Gabriel Barkay 